\title{
The Cinematographic Depiction of the Displaced Population
}

\author{
Luis Fernando Gasca Bazurto \\ Corporación Unificada Nacional de Educación Superior CUN, Bogotá D.C., Colombia
}

\begin{abstract}
The Colombian armed conflict has been represented in several films that have exposed the complexity of the problem. In this scenario forced displacement is a recurring theme. Based on this reality began a process of investigation that took as a starting point the revision of 160 synopsis of national films and 10 foreigners that had thematic violence in Colombia. The intention was to determine in which films the victim was represented by displacement and in what way. The method was an exploratory-descriptive documentary review. For the analysis, the concepts of Collective Imagination, Social Depiction and Semi-Imaginary Reality were taken as corpus. As a general conclusion, it is exposed that the representation of the victim in the national cinema is determined by the topics of Violence and Displaced Person that have varied in parallel according to the Colombian historical conjuncture. These configurations show the subject as a body transformed by the struggle of political powers
\end{abstract}

Keywords: Colombia, cinema, diaspora, imaginary, representations

\section{Introduction}

This document aims to socialize the advances and findings reached to date in the research project: Life stories of the displaced population and their film representation. For this process it was based on the concepts imaginary and social representation developed respectively by Cornelius Castoriadis and Sergei Moscovici. These notions are related to the cinema as an invention of the technique that represents social imaginaries and at the same time provokes new ones in the spectator public, as Edgar Morin (2001) points out. Since, a film is an act of representation that builds realities inspired by experience. Likewise, cinema builds memory, reflection and provokes perceptions about historical reality. However, a film is a point of view, an approach to reality permeated by practical, aesthetic or personal decisions. The spectator is influenced by the audiovisual narrative that incites him tensions with his own perception of the truth. This situation can be seen in the films: Retratos de un mar de mentiras (Gaviria, 2010) that tells the return, in Los Coloresde la Montaña (Arbeláez, 2011), where the naivete of the displaced is exposed, in Pequeñas voces (Andrade \& Jaramillo, 2012) remembers the distant terroir or in La Playa DC (Arango, 2012) describes the need to adapt to the new territory. Among others, the films mentioned show tensions caused by the Colombian armed conflict. These, directly or indirectly have configured the displaced subject as a permanent actor.

The assertions indicated start from the revision of 160 synopses of national and 10 international films that narrate the violence in Colombia. The revised period covers from 1946 to 2016. However, this review can not give a detailed reading of the entire national filmography since the information on the total of national films is wide, scattered and incomplete. In particular on violence there is a production outside the commercial exhibition

Luis Fernando Gasca Bazurto, Realizador de Cine y Televisión (Film and Television Director), Comunicación y Bellas Artes (Communication and Fine Arts), Corporación Unificada Nacional de Educación Superior CUN. 
circuits that has been exposed in independent areas such as art and rehearsal rooms, universities, the black market and even the Internet. So the present review is no more than an approximation and offer a general perspective on the chosen theme. A deeper work would require a complete compilation of the Colombian filmography for a detailed review of it, and not only of the synopses. However, this study shows the way in which national filmmakers have become interested in the phenomenon of violence, have addressed it and have seen and interpreted the presence of the displaced.

\section{Theoretical Framework}

Language is a complex symbolic system that helps build the world. For Lacan the stage of the mirror is the entry of the individual into the symbolic world through the verbal and allows the individual to relate to others. Reality is a symbolic construction that occurs through language. According to Capetillo (1991) for Lacan man enters the symbolized world at about six or eight months of age when he discovers himself before the mirror. This recognition is done by analogy in distinguishing itself from the others. Capetillo (1991) states that the child has understood this instance because his mother told him verbally each time he put it in front of the mirror and expressed, "You are that" (p. 356). The maternal statement is loaded with meanings for the child that allow him to identify himself. However, the symbolic not only strictly adheres to the verbal language because what the child observes in front of the mirror is his image. Well expresses Eco (2012) "Let's remember, in passing, that what Lacan calls the symbolic is the semiosic, even if it is a semiosic identified with verbal language" (p. 8). The reality is populated by different languages and many are made of images although there are some that in themselves are a language as it happens in art. The languages, the metalenguajes, the iconographies, among others are part of the reality and all this means something for somebody. So every act of human production is part of reality.

\section{Collective Imaginaries}

Collective Imagination (also Social Imaginary) is a concept originally developed by Cornelious Castoriadis. This term has a character that can refer to imagery and image. Imagination is the place where images are formed not in the sense of static graphic representation but of meaning, or something that contains a concept, a notion, for someone. Cegarra expresses (2012) that “(..) the imaginary must be assumed as a matrix of meanings that guides the meanings assigned to certain vital notions (love, evil, good) and ideologically shared notions (nation, art, etc.) by the members of a society" (paragraph 9). The imaginary is the exercise of conceiving reality from the human capacity that Castoriadis designates as imaginary. The imaginary capacity is the construction of senses and not of images. The imaginary is a non-individual social act. For example, fundamental principles such as good, evil or nation are possible social elaborations through the imagining capacity during the historical evolution of society. Cegarra (2012) aptly says that "the social imaginary is an external condition" (para. 9). For it is a non-scientific reasoning that springs from the creation of the community. This creation takes place on "vital" and "ideological" notions. Since, according to Agudelo (2012), "The conditions of domination of a social class depend on the imaginary. In this perspective, the imaginary can be defined as the sets of ideas-images that serve as relief and support to ideological forms such as the founding political myths of institutions of power" (p. 5). Since social imaginaries explain the origin of hegemonic powers and what legitimizes them.

Ideology is a shared discourse that determines rules and social behavior within a hierarchical structure in which there is a dominant class and a subdued class. In that configuration the hegemonic class creates discourses to keep itself in force and to hold individuals. Notwithstanding these instituted dispositions also they 
form the identity of the social groups. Robertazzi (2007), on the subject of Girardet, considers that prototypical mythical configurations exist in all societies and form the imaginary dimension as agents that mobilize collective fears and hopes. For, as Fernandez (2016) puts it, "the imaginary show the stability and reproduction of the instituted (social imaginary instituted) and on the other hand the social rupture demarcates the elaboration of new social imaginaries (establisher) that account for the power of invention social" (p. 6). That is to say, the imaginary exposes political tensions within the groups and an adequate reading would allow discovering the matrix of the hegemonic structures that are manifested in the configuration of the myths, the stories and that which transmits and sustains those powers in a society.

\section{Depictions}

Symbolic elaboration is a human quality that comes from the ability to abstract, represent and create meanings. To represent is to present what is already present. For example, an artist represents his concept of the world but it is not the world but an interpretation. However, the artist is not the only one who represents because the individual of the common also does. A man tries to understand what he has before him and makes deductions to express them to his fellow men who also create assumptions. In this process of sharing what in the judgment of each person is the reality arises what are called social representations. The concept of social representation (Social Depiction, in the case of this article) is a "preparation for action" according to Sergei Moscovici $(1979$, p. 6). The author states that the social individual constantly analyzes his environment in a practical way. But this is constantly changing by technology, politics, climate, etc., which determines that the notions of something are transformed by circumstances and the social entity confers new meanings. For Banchs (1986) social representations refer to "those knowledge that are collectively elaborated in the face-to-face community and which deal with a significant object within a collective" (p. 36). The author alludes to the knowledge developed together "face to face" about a particular thing. That thing or object is that which means something to the social being. By way of illustration, the word peace is an object that in the Colombian context of the peace agreements between the government and the Farc-EP means reconciliation for one group while for another it is a nonsense.

The mental image that the individual has elaborated is not necessarily an iconic construction but an abstraction of the object. Social representations are the ways in which societies appropriate concepts, ideas, events and so on to make them understandable to their everyday environment. The media and technology make social groups constantly impacted with information, which makes social representations more dynamic than before. News in communicative exchange can acquire one or more meanings for a community through what Moscovici (1963) calls "common sense" (p. 21). All discourse is enunciated from a language but, according to Araya (2002), verbal language is the one that most intervenes in the elaboration of social representations because it is with which the individuals interact more. According to the author an iconic image is static but an image understood as a social representation is dynamic because every object is constantly transformed into the future of events. However, it can also be inferred that an iconic image is also susceptible of transforming its meaning for a community according to the historical conjuncture. In any case, a social representation is an act of thought.

\section{Semi-imaginary Reality}

Man interprets, creates and transforms his reality imaginatively. For Morin the cinema does not work simply in the manner of a portrait or a simple photograph that embodies the already seen. Rather it is very 
similar to naive or naive painting. The naif was characterized because the author's spontaneity surpassed or ignored the technique. The supposed errors of perspective, composition, chromatic harmony, etc., externalized ideas, feelings or fears and ignored the factual reality. Naive painting simply projects the soul. In the same way, cinema assimilates the world through the spirit to reveal man and "practical and imaginary realities" (Morin, 2001, p. 188). The practical reality of producing is found in the cinema with the unproductive reality of imagining. Likewise, it is the place where man converges with his psyche. The term psyche aims at psychology but it is also the consciousness understood as a spiritual force that feels and creates. That is why Morin (2001) expresses "Cinema offers us the reflection not only of the world, but of the human spirit" (p. 179). The psyche is understood in the sense of aesthetics in the necessity of creation and in the pleasure of recreation. For in a film projection the psyche of a creator flows to the observer who delights in it and reinterprets the world. Well, Morin (2001) stated that "The screen, a new look, imposes itself on ours" (p. 180). Man understands imagining and reasoning. But the cinematograph is also alignment because there are the looks of "the other ones" (Morin, 2001, p. 189). All construction of identity is the union of those that already exist as demonstrated by Lacan in the mirror stage or as Capetillo (1991) interpreted it with the maternal utterance "You are that" (p. 356). In the same way the cinematographic projection is an alienating statement that asks of the spectator its identification with the seen thing there. However, "the other selves" are not only men but what Morin (2001) calls "the subjective consciousness of the world" (p. 185). It is a die Geisterwelt in the Hegelian sense, it is the way in which reality thinks itself but through the human spirit that in this case is prosecuted through the cinematograph. That is, man thinks and expresses reality through the cinematograph and shares it, but that sense of reality is transcendent because it surpasses in time the men who proposed and received it.

Thus man and cinematograph acquire a cosmogonic quality because they build again and again the world in which they live. That consciousness is collected, projected and returned by the cinematographer. Man is confirmed in the subject of the world, but in this way he humanizes and makes it his own through the thought projected on the machine that allows him to see it, dream it and devise it. The world is illusion and truth only in the cinema "the imaginary is determined by the machine" (Morin, 2001, p. 189). This determines that the creator of the film and the spectator have their own divided soul there. Thus for Morin "the reality of man is semi-imaginary" (p. 185). Morin is right in saying that the reality of man is divided because in one place is the symbolism that he needs to interact and communicate with the world and in another the imagination that in a certain way allows him to oppose or project to the future. From this perspective the cinema is union and opposition between technique and art, reality and imagination. That awareness has been aligned in the cinema that shows and provokes the participation of man in the world and in history. The semi-imaginary reality that Morin observes in the cinematograph is not only a representation of reality in the mimetic sense of Aristotle, but also in the direction of Moscovici to represent. More than that, to imagine Castoriadis saying. Morin's idea of thinking about cinematography in this way also puts it as a machine that projects and creates imaginaries and social representations. For, as it represents, it envisions new senses that allow us to re-imagine the way of transforming transcendent objects for society such as war, peace or forced displacement.

\section{Methodology}

One hundred and seventy synopses of films about the violence film in Colombia were reviewed to determine where the issue of armed conflict was present and where the displaced person was present. For this, the descriptors were prefixed: cinema, Colombia, violence, and politics. From 1926 to 2016, one hundred and 
sixty national and ten foreign films were identified. Next, a table was designed in Excel to be systematized by columns as follows: year, genre, films that approached the topic and those that did not. In this process, three categories associated with violence were identified: political violence, armed conflict and drug trafficking. Next, the synopses were cataloged in Excel sheets from 1926 to 2011, then from 1965 to 2012 corresponding to foreign production and finally one for each year from 2012 to 2016. The intention of this grouping was to facilitate the analysis because in groups one and two production is scarce while in three it increases considerably. In fact in the first group forty-two films were found, in the next ten and in the last one hundred nineteen. Each table was ordered according to the topics: No., Year, Title, Genre, Director, Synopsis, Cinema of violence, Direct presence of the displaced, Indirect presence of the displaced. As an illustration, Table 1 shows the classification indicated for two synopses corresponding to the year 2016.

Table 1

Sample Classification of the Synopsis Revised in 2016

\begin{tabular}{|c|c|c|c|c|c|c|c|c|}
\hline No & Year & Title & Film genre & Directed by & Synopsis & $\begin{array}{l}\text { Cinema } \\
\text { violence }\end{array}$ & $\begin{array}{l}\text { Direct } \\
\text { presence } \\
\text { of the } \\
\text { desplaced }\end{array}$ & $\begin{array}{l}\text { Indirect } \\
\text { presence of } \\
\text { the desplaced }\end{array}$ \\
\hline $1 \mathrm{st}$ & 2016 & $\begin{array}{l}\text { Inflated } \\
\text { jungle }\end{array}$ & Documentary & $\begin{array}{l}\text { Alejandro } \\
\text { Naranjo }\end{array}$ & $\begin{array}{l}\text { The young native inhabitants of } \\
\text { the Colombian Amazon are } \\
\text { committing suicide. Because white } \\
\text { men came with the evils of the city.. }\end{array}$ & Not & Not & Not \\
\hline 2nd & 2016 & $\begin{array}{l}\text { Two } \\
\text { women } \\
\text { and a cow }\end{array}$ & Fiction & $\begin{array}{l}\text { Efraín } \\
\text { Bahamon }\end{array}$ & $\begin{array}{l}\text { Hermenilda needs to know what } \\
\text { happened to her husband, who was } \\
\text { recruited by a rebel group. One } \\
\text { day Hermenilda receives a letter } \\
\text { from her husband but she can not } \\
\text { read. Then he travels with his } \\
\text { mother-in-law and his cow to a } \\
\text { nearby town for someone to read } \\
\text { his letter. However, the village } \\
\text { was attacked and they must return } \\
\text { home to escape the war. }\end{array}$ & Yes & Yes & Yes \\
\hline
\end{tabular}

Note. Source of information: Table designed based on information from Proimágenes Colombia 2016.

It was identified with an affirmation (yes) that synopsis that expressed presence of the displaced person or with a negation (no) otherwise. Subsequently a new table was designed to compile the first results interpreted in numerical quantities according to the number of films of each theme. This interpretation allowed for a level of quantitative analysis. The new table was divided into the following items: Total, Year, Fiction, Violence Fiction, Documentary, Violence Documentary, Violence Film, Other Themes, Direct Presence of the Displaced and Indirect Presence of the Displaced. In the case called Cinema of violence, the sum of the fiction films and documentaries of the topic is collected. As an example, Table 2 presents the year 2016.

Table 2

Compiled From the Year 2016

\begin{tabular}{|c|c|c|c|c|c|c|c|c|c|}
\hline $\begin{array}{l}\text { Total } \\
\text { Films }\end{array}$ & Year & Fiction & $\begin{array}{l}\text { Violence } \\
\text { Fiction }\end{array}$ & Documentary & $\begin{array}{l}\text { Violence } \\
\text { Documentary }\end{array}$ & $\begin{array}{l}\text { Violence } \\
\text { Film }\end{array}$ & $\begin{array}{l}\text { Other } \\
\text { Themes }\end{array}$ & $\begin{array}{l}\text { Direct } \\
\text { Presence of } \\
\text { the Displaced }\end{array}$ & $\begin{array}{l}\text { Indirect } \\
\text { Presence of } \\
\text { the Displaced }\end{array}$ \\
\hline 9 (Nine & 2016 & 5 (Five) & 3 (Three) & 4 (Four) & 0 (Zero) & 3 (Three) & 6 (Six) & 3 (Three) & 3 (Three) \\
\hline
\end{tabular}

Note. Source of information: According to the classification of Table 1. 
Table 2 shows that of nine synopses examined in the year 2016, five are fictional and four are documentary. Of the total, only three deal with violence and correspond to fiction films while six focus on other issues. An analysis like the one exposed was extended to each of the classifications to determine the presence of the displaced in the chosen films.

\section{Results}

One hundred and sixty synopses of Colombian films and ten foreigners from 1926 to 2016 were reviewed. From 1926 to 1946 there is a vacuum because the films did not comply with the themes as established for this review.

Table 3

Below Presents the Compiled Summary

\begin{tabular}{|c|c|c|c|c|c|c|c|c|c|c|}
\hline No & Total & Year & Fiction & $\begin{array}{l}\text { Violence } \\
\text { Fiction }\end{array}$ & Documentary & $\begin{array}{l}\text { Conflict } \\
\text { Documentary }\end{array}$ & $\begin{array}{l}\text { Violence } \\
\text { Film }\end{array}$ & $\begin{array}{l}\text { Other } \\
\text { themes }\end{array}$ & $\begin{array}{l}\text { Direct } \\
\text { Presence of } \\
\text { the Displaced }\end{array}$ & $\begin{array}{l}\text { Indirect } \\
\text { Presence of } \\
\text { the Displaced }\end{array}$ \\
\hline 1 & 1 & 1926 & 1 & 0 & 0 & 0 & 0 & 1 & 0 & 0 \\
\hline 2 & 41 & 1946 / 2011 & 29 & 6 & 12 & 12 & 18 & 23 & 12 & 18 \\
\hline 3 & 10 & 1965 / 2012 & 0 & 0 & 10 & 10 & 10 & 0 & 1 & 3 \\
\hline 4 & 24 & 2012 & 20 & 2 & 4 & 0 & 2 & 23 & 2 & 0 \\
\hline 5 & 17 & 2013 & 14 & 1 & 3 & 0 & 1 & 16 & 0 & 0 \\
\hline 6 & 30 & 2014 & 16 & 5 & 4 & 1 & 6 & 24 & 1 & 3 \\
\hline 7 & 38 & 2015 & 31 & 4 & 7 & 2 & 6 & 32 & 10 & 7 \\
\hline 8 & 9 & 2016 & 5 & 3 & 4 & 0 & 3 & 6 & 3 & 3 \\
\hline 9 & 170 & 1926 / 2016 & 116 & 21 & 35 & 15 & 36 & 126 & 29 & 32 \\
\hline
\end{tabular}

Note. Information source: Own design.

In Table 3 line 1 corresponds to the film Garras de Oro (Cali Film, 1926). This is an early history of political cinema as it shows the loss of the isthmus of Panama as a consequence of the War of the Thousand Days. In row 2, it can be observed that from 1946 to 2011 the national film production was scarce but of forty-one synopses studied eighteen evidenced the topic of violence of which twelve correspond to the documentary genre. It is also noticed that in the total of the eighteen films the displaced person is presented directly and indirectly. Row 3 corresponds to the films on the topic produced abroad. This production covers the year 1965 to 2012 and was addressed to the documentary genre. Although all production focuses on the issue of violence, the displaced only appears directly in one film and indirect in three. Of these ten films seven are of French origin, one from Cuba, one from the United Kingdom and another from Denmark. From 2012 to 2015 there is a notable increase in national film production but the number of films dedicated to violence decreases and interest in other topics increases. In this period the presence of the displaced remains consistent with the number of films produced about violence. However, as indicated in row 7, in 2015 the trend changes and there seems to be a contradiction because of six films focused on that theme, in ten of them, the displaced person is presented directly. In seven, cases, it was indirectly. This responds to the fact that this year, national filmography starts being interested in depict other forms of displacement not caused by violence.

\section{Results Analysis}

The conjointed review revealed that the theme is separated into different stages. The first of 1926 to 1946 expresses that the interest was not oriented towards the political situation except for a history of 1909 and 
another one of 1926. In 1909, it indicates Salcedo (1981), a photographic sequence was produced that illustrates the attack to the general Rafael Reyes denominated The ten of February that was published in the book Repúblicade Colombia - Excursiones presidenciales (1909) of Pedro A. Pedraza. The second one is the film Golden Claws (Cali Films, 1926) that narrates the separation of Panama caused by the War of the Thousand Days. Except for the aforementioned antecedents, the national cinema did not continue to be interested in politics until after the 1950s because, according to Salcedo (1981), those interested in producing films tried to emulate the themes and forms of foreign cinema that was most welcome among the public Colombian. On the other hand, the absence of state policies that facilitated the national film production and its commercialization prevented the filmmakers from gaining enough experience to dare to expose other matters. However, the exception was the Acevedo brothers who, as Salcedo (1981) explains, since 1924 have constantly produced newscasts for the cinemas about various events of national life among which we can mention Peru invades us (1932) and Semana of democracy in Bogota (1946). In the latter describes the political tension that society was already living in the 1940s and explodes with the assassination of the liberal leader Jorge Eliecer Gaitán that unleashed a great assault on the city of Bogota at the hands of the enraged crowd. The event described was also documented by the Acevedos in the film El Bogotazo (1948). The last two films sign the beginning of the second stage identified in this study that covers from 1946 to 1965 period corresponding to the same that the national history popularly calls La Violencia. This period will also be characterized by the preponderance of the documentary genre over that of fiction. At this early time the filmmakers record the facts in a descriptive way and maintain the news format used by the Brothers Acevedo. The mobility allowed by the documentary genre is one of the reasons why of the twenty-four films produced from 1946 to 1990 on the nineteen violence were documentaries versus five of fiction. This trend is going to be maintained throughout the national production and means that it is for costs or for the force that has to present the vivid reality the documentary has been the audiovisual instrument most used by the national and foreign filmmakers to narrate the violence in Colombia.

The descriptive approach also influenced fiction. An example of this is the short film Esta es mi vereda (Canal, 1959) that halfway between fiction and documentary narrates how the simple life of the countryside is interrupted by bipartisan violence that bursts steamily to divide the inhabitants of the place. This is the first film that warns about forced displacement. Towards the second half of the 1960s the period of violence ended with the death of the last bandits and the beginning of the leftist guerrillas. It is a turning point because the conflict between liberal and conservative hegemonic powers turns to the confrontation between the State against the rebel groups. Similarly, filmmakers leave descriptive narrative to take on more direct political positions and address the social causes underlying the phenomenon of violence. From this time the documentary Rio Chiquito (Muel and Sergent, France, 1965) narrates the bombing carried out by the Colombian air force on the population of Marquetalia happened in June of 1964 and the consequent birth of the movement Revolutionary Armed Forces of Colombia - Army of the People (Farc-EP). In 1966 the films Camilo Torres (Muel and Sergent, France, 1966) and Camilo Torres Restrepo (Giraldo, 1966) document, first, the departure of the priest Camilo Torres to the clandestinity to support the left-wing guerrilla group Ejercito de Liberación Nacional (ELN) in response to the repression of the ruling class against the new political forms. The second documentary was made by the students of the National University of Colombia headed by Diego León Giraldo and tells the funeral of the priest Camilo Torres after his death and transfer to Bogota. This film presents the student not only as a mere observer but as a social actor who takes the camera to appropriate and be included in the 
situation that affected him. As Becerra (2017) puts it, "The center of gravity of our '68-likecinematographic revolution rests in the student movement, in the student as a new urban and film subject, around debate and public space, in the public university" (p. 221). This is a radical change in the way violence was narrated to date since the camera was not only used to show but was transformed into an instrument of confrontation against the state. It is not only a period of change on the audiovisual doing but the task determined by the awareness of the young people who assumed themselves as actors and builders of history.

In the early 1980s, a reencounter between the Violence topic and the filmmakers that I myself call "Documentalist-Revisionist Period". On one hand there are different episodes of rebel groups against the state. On the other, the focus is returned to the era of violence. Being the first way of documentary character and the second of fiction. The documentaries of this period continue with the political route traced from the sixties but are not well known. In this plot, the documentary La ley del monte (Castaño \& Trujillo, 1989) shows the struggle of settlers expelled from their territory by violence and their settlement in the lower Caguán, Amazonia and Macarena region. The film is made by two women who reveal the problem of displaced people who instead of migrating to the big city do it to inhospitable places causing pressure on the environment by sowing illicit crops. At this stage the fiction cinema has few products on the subject although it manages to express the situation of displacement in different situations. Canaguaro (Kusmanich, 1981) tells the formation of the guerrillas in the plain after the death of the liberal leader Jorge Eliécer Gaitán and the subsequent persecution and annihilation of their leaders. In this context families leave their territory to flee state forces or to swell the rebel ranks. In a very close way El Potro Chusmero (Sanchez, 1985) tells the persecution of the Chulavitas to a group of chusmeros and the excesses that they committed against the peasants. In this film the little colt owned by one of the rebels symbolically represents the innocent who remains in constant state of siege and flight. The well-known Condors do not bury every day (Norden, 1985) based on the novel of the same name written by Gustavo Álvarez Gardeazábal narrates the rise and fall of Leon Maria Lozano one of the most famous assassins and accomplices of the conservative state to whom the writer put the mote of condor to him adducing to the king of the birds. The film tells the main character the way in which armed groups intimidated to displace or assassinate those who considered the party's enemies. Of this stage Pisingaña (Pinzón, 1985) has the direct protagonist to the displaced person. Through the story of a young peasant named Graciela, the film describes, after the murder of her grandfather, her rape and flight to the great city where she is subjected to the servitude of a middle-class family. The film is a portrait of the before, the after and the unfortunate outcome of the character.

The last stage of 1990 to 2016 covers almost two decades of national filmography. In 1990, according to Nieto, Gómez, and Moya (2005), only three films are released and are part of the genre of fiction. The low production was caused by the decline of Focine and the subsequent liquidation of the entity in 1993. The initial scenario of 1990 was reversed in 1997 with the creation of the Fondo Mixto de Promoción Cinematográfica (Proimágenes Colombia) and the approval of the Cinema Bill in 2003. The new policies contributed to the increase of the national production that also facilitated the approach of other thematic ones. Today the national cinema exhibits different titles year after year even of gender and shows different social realities. At the same time, the issue of violence becomes more complex given the entry of new actors to the stage. In this period, the armed confrontation between the state and the guerrillas is no longer just a direct confrontation of the institutions against the drug gangs, the combos of the outlying neighborhoods of the big cities, and the paramilitary organizations. The panorama of violence in Colombia had become more complex and the national 
cinema exposed it. It shows the three films released in 1990: Rodrigo D: No Futuro (Gaviria), Amar y Vivir (Duplat) and Confesión a Laura (Osorio). The latter returns to the origins of bipartisan violence. The story goes on during the Bogotazo and tells the hours of anguish of a mature school teacher named Laura who sheltered in his apartment next to Santiago, a public employee, wait for calm to return. Circumstances serve to bring between them repressed feelings and frustrations. In this film the political violence unleashed in the streets is a catalyst for internal conflicts, banalizing the Bogotazo event by transforming it into a pretext. On the other hand, other two films try to portray the new type of violence forged in the world of drug trafficking. In Rodrigo D: No Futuro (Gaviria, 1990) the atmosphere of the young inhabitants of the poor neighborhoods of Medellín that make up small criminal gangs is exposed. Rodrigo D is one of those young people who will die before their twenties due to lack of opportunity or the inevitable modus vivendi of the sector.

From another perspective, Amar y Vivir (Duplat, 1990) is a sequel to a successful television series that tells Joaquín's romance - a young man expelled from his village by a chieftain - and Irene, a humble working girl from a marketplace who dreamed of be a singer. The story shows two paths of progress for the characters: Joaquin achieves economic success by becoming a small gangster but ends up in jail, on the contrary Irene honestly fights against adversity until materializing his dream. Both the television series and the film exposed a moralizing teaching that advocated achieving dreams through honest work and punishment for anyone who chose the path of evil. The two films mentioned show two facets of the displaced. Rodrigo D in the future does not directly expose young offenders to being displaced. However, as Naranjo and Hurtado (2004) put it, "Colombian migrants from the 1940s onwards come from a large majority of peasant or small-town communities and were distributed in different regions, departments and cities, large and intermediate" (p. 9). Following the exposed reality the young people of the film are descended from the forced displacement that in the past suffered their parents and grandparents who were forced to leave their plots and migrate to the urban centers to settle subnormal way in the periphery of the city. In these territories, certain peasant customs are still perceived as the Chircales (Rodríguez \& Silva, 1972) film, which recounts the social conditions of the workers of the chircales exploited by landlords, had been shown years ago. In Amar y vivir (Duplat, 1990) the young displaced is a victim of his eagerness to survive in the city, his desire to achieve his dreams and the ghost of revenge that throw him into a life of delinquency. In the film achieving the economic solvency to achieve their dreams, including revenge, is the journey of fate that induces to follow the easy way. The subtext common to both stories is the displaced tornado from victim to actor of violence.

In 1996 the film Edipo Alcalde (Triana, 1996) resumes the tragedy of Sófocles with script by Gabriel Garcia Marquez to describe the impotence of a town mayor who finds himself in the midst of the conflict between guerrilla and paramilitary. The film presents violence as a fatal and inescapable fate of the gods and therefore unsurpassed. It shows the disenchantment from what Morin (2001) would call the "subjective spirit of the world". In this case, that spirit is impotent society, gathered in their fears and without any hope of getting out of the crisis because of the violence unleashed by drug trafficking and Guerrillas. And since the 1990s, Colombia has known the highest level of violence in its history. The circumstances of this upsurge, as Castilla (2001) points out, begin in 1990 after the fifth summit of the Simón Bolívar Guerrilla Coordinator in which it is decided to attack the military forces and the country's infrastructure. From 1992 to 1995, violence increased with the operations of the military. In 1999, the violence declined on the occasion of the table of dialogues of San Vicente del Caguán that was installed in 1998 during the government of Andres Pastrana. This stage of complexity goes to a new phase with the appointment of President Álvaro Uribe Vélez who, after the failure of 
Caguan and during two continuous presidential periods, increases more than before the actions against the guerrillas. However, from 2002 to 2010, which includes the Uribe government, the violence cinema focuses in more detail on the direct drama of the victim.

For example, the first night (Restrepo, 2003) relates the situation of the displaced who arrives in the city and without any resources he must spend the night in the street subjected to the siege of those who try to strip him of what little he has left. Here the city is the place of rapine and ruthless indifference. In Heridas (Flores, 2008) displaced victims are shown trying to reunite themselves with what remains of their disjointed family. Retratos deun mar de mentiras (Restrepo, 2010) tells the story of the victim who already settled subnormal in Bogota decides to return to their territory to claim their land. However, there are possessed paramilitaries who are determined not to surrender the spoils won. This film takes advantage of the debate that was given in the congress and then in 2011 is reflected in Law 1448 that in Article 103 creates the Land Restitution Unit. This entity as a quotation Navarrete (2014) "Process to the competent authorities the processes of Land Restitutionto the dispossessed or formalization of properties abandoned on behalf of the owners, in the cases provided in this law" (paragraph 2). This film takes advantage of the alternating debates that influence the conception of the story to express situations that were actually under discussion.

In 2010, the films Pequeñas voces (Carrillo \& Andrade, 2010) as well as Los Colores de la Montaña (Arbeláez, 2010) examine violence from the child's point of view. The first film is unique because it picks up the voices of the true children protagonists and their experiences to expose them in Animation and Motion Comics Illustrations inspired by the drawings of them. The story gives a complete picture of the victim since he is in his land until he must abandon it by violence to move to the city. This is an innocent look, not without criticism and crudeness that does not lose the optimism that characterizes the dreamy perspective of a child. The second film shows the adventures of a group of children who lose a soccer ball in a minefield. While the infants devise strategies to recover it around the violence invades the whole environment until each of them leaves with their family. At this stage the consciousness of the filmmaker follows the side of the weaker characters. The difference is that it delves into the way the situation affects the family and its internal and external relationships. A look that emphasizes the way violence disarticulates or mutilates the family cell.

2012 to 2016 is the period of the Peace Process. At the moment the national filmography is abundant in quantity of films and themes. Here are some of the topics that were being treated but the director's eyes become more intimate. In parallel, there are other causes of displacement outside the violence. About the violence movie La Sirga (Vega, 2012) relates the experience of Alicia who arrives at his uncle's hostel escaping from someone. There it remains sheltered until the return of its cousin who incarnates the evil forces it to flee again. In this film the displaced is an individual in forced transit no longer by a rebel group or defined criminal but by the same evil that stays latent waiting to attack. In La Playa DC (Arango, 2012) a young Afro descendant expelled from his home by his stepfather arrives in Bogotá to look for his brother who lives in destitution. Meanwhile, he works informally in the Bogota sector known as the beach to earn money and emigrate to the United States. The film shows how the situation of the two brothers is the result of the murder of the father by an undefined armed group. In Porfirio (Landes, 2012) a disabled person hijacks a plane to catch the attention of the government. In these two films the victim does not remain victimized but tries to forge a destiny. From this stage, Jardin de Amapolas (Melo, 2014) continues on the path of showing the conflict from childhood innocence.

The national premieres of the year 2015 present non-violence displacement causality. In this year ten films were released, some of these are: The valley without shadows (Mendoza, 2015) is a documentary that presents 
to some of the survivors of the avalanche that buried to the population of Armero in 1985; La Tierra y La Sombra (Acevedo, 2015) is the story of a family who must abandon their plot located in the middle of the big cane fields because of the harvested cane remains burning ashes and the lack of work, that make the place inviolable; Monte Adentro (Alonso, 2015) is a documentary that shows the end of the muleteer job and the horizon of uncertainty that opens up for those who still live from it; Parador Húngaro (Suárez, Aleksander, 2015) is about people who do not belong anywhere incarnated in two foreigners named Aleksander and Víllas, a Hungarian who escaped communism and installed a hostel. In 2016, 9 synopses were reviewed, of which three correspond to fiction films that deal with violence and show the displaced directly. These films return to familiar topics of escape, uprooting and uncertainty. In Dark Animal (Guerrero, 2016) shows the abandonment of the victim in the big city and the effort to adapt to the new life. Siembra (Lozano \& Osorio, 2016) expresses the displaced person's nostalgia for his homeland and the feeling of going back to it. Dos Mujeres y una vaca (Bahamón, 2016) is a story from the female point of view that tells the story of a grandmother and her granddaughter Hermelinda who looks for her missing husband with a cow, his only heritage. The film returns to the contingent causality that produces the displacement victim. Although the film puts the victim back in the place of the innocent harassed, the eye is rescued from the woman who in one way or another is in charge of preserving the home. In this way, the panorama traced to date allows to locate historical moments and the way in which they influenced the cinematography. It also allows us to infer the ways in which national cinema has exposed the mutations of political violence and the displaced as its direct consequence.

\section{Conclusions}

The Colombian Cinema of Violence necessarily registers as the main object from the point of view of social representations and the displaced as its consequence. Social representations are the objects that a society interprets to grab its world and its identification allows to distinguish the ways in which they reinterpret it as Araya (2002) says. For this case, they are taken from the point of view of the community of audiovisual filmmakers and cinema as language. The audiovisual director is understood as a historical subject that through the language of cinema interprets social objects and proposes new meanings about the social evolution. On the other hand, cinema is reproductive and "myth-making" (p. 15), as expressed by Gubern (1992), which expresses the sentiment of society. In the same way, the cinematographer reproduces them and returns them to the community who sees what Morin (2001) called "the subjective spirit of the world" (p. 185). In this sense the Collective Imaginaries are understood as the way in which the communities imagine their situation and give answer to the social division or to create myths that institute them or that they oppose to the first ones from an institutional position.

Based on the above, violence is the social object that serves as the axis of other social representations that has produced the Colombian Industry. In the same way the displaced is the first object determined by the first. These two objects evolve in parallel with the maturity that reaches the national cinema and the history fixed by the socio-political causality. In principle by the bipartisan division between liberals and conservatives, then by the emergence of social conditions to the contingent complexity that in the 1980s determined the entry of actors such as drug trafficking and paramilitaries.

Figure 1 shows how the objects of Violence (above) and Displaced Person (below) evolved in the development of national cinematography from 1948 to 2016. The way in which Violence is transformed as a result of political bipartisanship, recent productions show some sort of Ghosts of the Past as the "Evil" entity 
that remains in the air, although violence is no longer the main issue. On the other hand, the originally displaced individual is assumed in the peasant as a subject that passes through different stages to become an actor of violence, then an individual in transit until expressed in the female figure of the mother as responsible for holding the family together dismembered

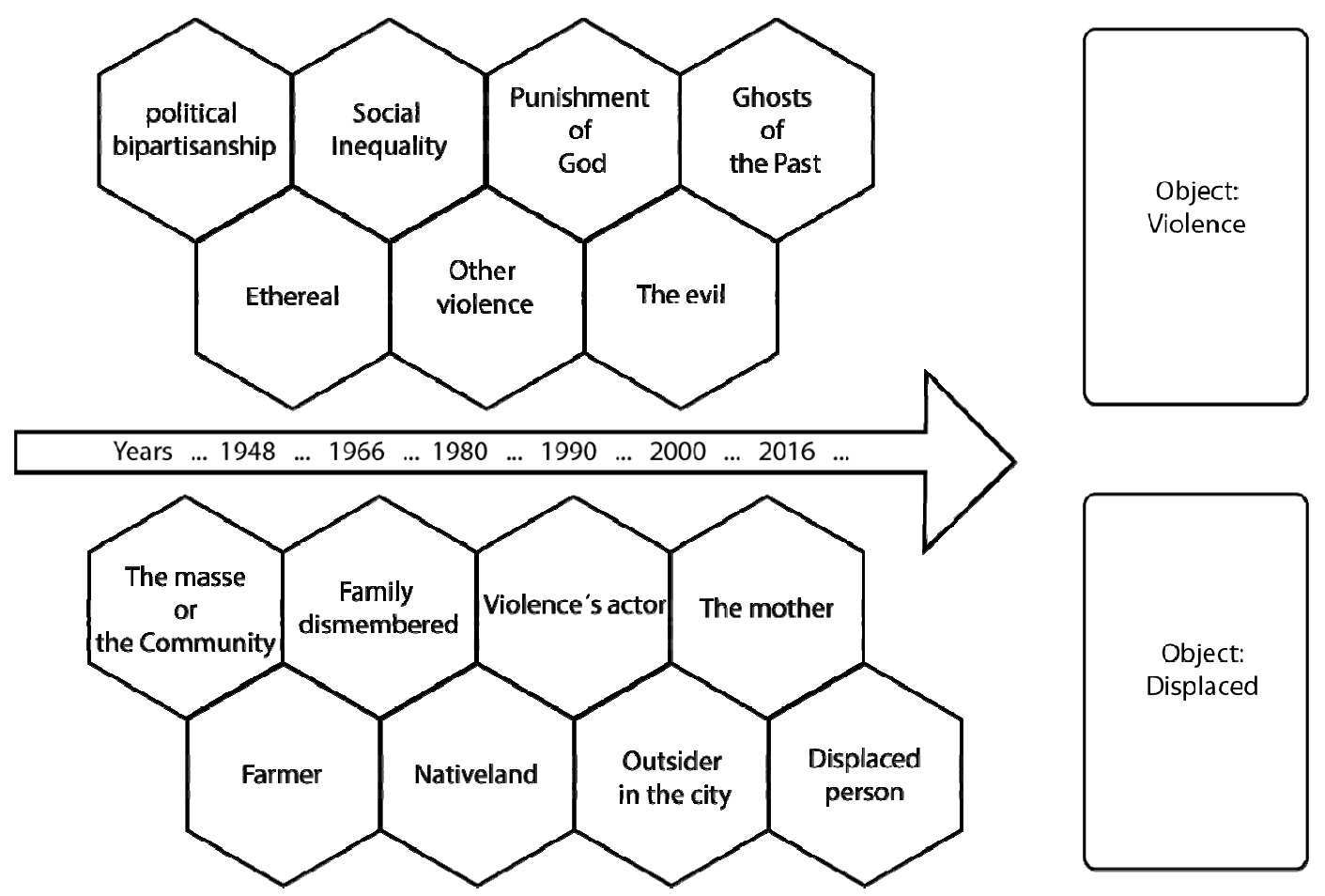

Figure 1. Evolution of objects: Violence and displaced person.

The Cinema of Violence at the beginning exposed the social representations that already existed and were disseminated in stories and news reports. Objects such as rabble that appealed to the mass, Chulavita to the government repressive police or bird that pointed to the killers who supported the statute showed in the cinema terms already usual in the fields to name one of the actors of violence. In this period of confusion where the neighbor turned against the neighbor the mass media considered that the mass was responsible for the violence because his political passion had disrupted it. It was believed that the peasants gathered on one side or the other and assassinated each other with the commitment of people at the service of the government or the opposition. However, cinema maintains the distance of this perception because the first documentary films simply narrate the facts and the fiction as in Esta fue mi vereda (1959) presents the violence as an indecipherable fact, although it is signified to the political division. In the later national filmography on violence the peasant was configured not as a man but as a people. This is a sign of the Marxist affiliation of some filmmakers who saw in the mass the historical entity opposed to the state servant of the capitalist class. In this way two new objects are proposed, the state as a repressor and the people in struggle. However, this mode of representation concealed the individual as shown by Rio Chiquito (Muel and Sergent, France, 1965). There the faces of the numerous peasants who escape the bombings keep distance of the individual subject. The same idea continues to be collected at different times by other productions such as Canaguaro (Kusmanich, 1981) and El Potro Chusmero (Sánchez, 1985) that also exteriorize the disenchantment with the liberal politicians who deceived and betrayed them. In this way the politician becomes an actor and at the same time an object that circulates in the filmography of violence. It is no 
longer the affiliation to a party but simply the politician who deceives, promises and does not comply. There is a widespread perception that is expressed daily in the media, in the mouths of people and in the cinema that shows the political class as opportunist.

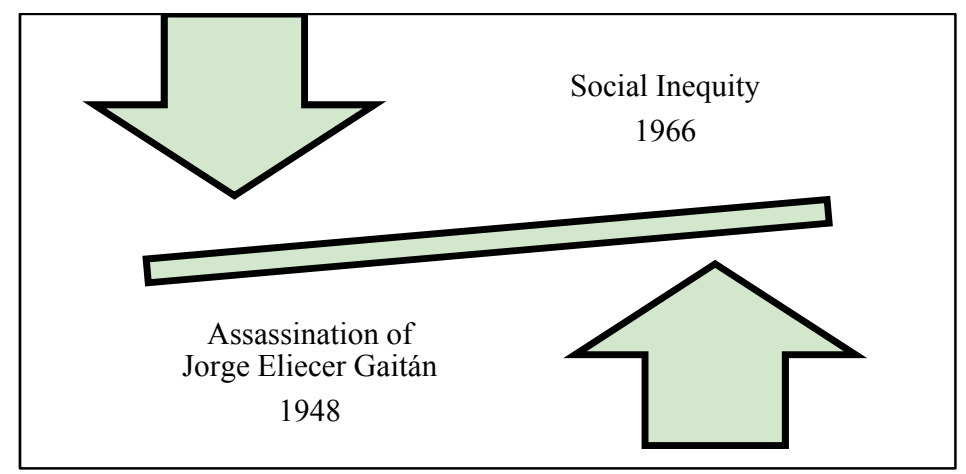

Figure 1. Tension of foundational imaginaries about violence.

A separate and determinant case was the entry to the map of violence of the Faculty of Sociology of the National University of Colombia, which, founded in 1960, presents a rigorous study on the phenomenon that was reflected in the book Violencia en Colombia: Estudio de un proceso social (1963) by Eduardo Umaña Luna, Germán Guzmán Campos and Orlando Fals Borda. The new actors: student movement and sociologists, rejected the foundational myths and denounced that violence was a direct consequence of social inequality induced by a class that was wanted to maintain. The indicated voltage is shown in Figure 2.

The contingency of the assassination of the liberal leader Jorge Eliécer Gaitán and the disorderly uprising of the town that wanted to take revenge in the remembered facts of the Bogotazo are two founding events of the story of the violence that are maintained throughout the national filmography. From El Bogotazo (Acevedo Bros, 1948) until the 1960s, and even, until the present century with Roa (Baíz, 2013). In this way the death of Gaitán and the Bogotazo are installed in a certain way as foundational myths of the theme that includes what the media, the historical documentation and the common society agreed on what was the germ of violence in Colombia. There is also a social imaginary that exposes in addition to the bipartisan division the separation of class. On the one hand the struggle of the two hegemonic political forces represented in liberals and conservatives. On the other hand, the assassination of the liberal leader Jorge Eliécer Gaitán who showed himself as the savior and hope of the people. In this early time in the filmography of violence, the displaced had no face as did the perpetrator of violence, but in the study of Umaña, Guzmán and Fals Borda (1962), the exiled peasantry materializes in the family. The authors describe the way in which armed groups devised different practices of intimidation and terror to expel the raizales from their territory. They report that the father was beheaded, the limbs of the children were amputated or the mothers' bellies were opened. The body of the family has been in the conflict the place of power and therefore it is mutilated. In the same way it was illustrated in some media of the time, in chronicles, graphic and written reports. The displaced object transformed into the mutilated family is first observed in the filmography of violence in the prequel to the film Camilo Torres Restrepo (Giraldo, 1966) and later in Pisingaña (Pinzón, 1985). In this the family is represented in the decapitated grandfather. The body as a place of power and confrontation is exposed in the subsequent violation of Graciela that in a certain way is repeated in the city when acceding to the request of his employer who wishes to have relations with her. 
In 1990, the only three films to be produced - Rodrigo D: No Futuro (Gaviria), Amar y Vivir (Duplat), and Confesión a Laura (Osorio - show rather that violence has multiple faces and is indefinable). Later in Edipo Alcalde (Triana, 1996) the armed conflict presents itself as an endemic evil that is expressed in the disenchantment of society before an unsurpassable situation. Here the map of violence is so confused that it is impossible to reconstruct it to find a way out. The social body is so mistreated that there is no more explanation than the implacable metaphor of fate. Here it is accepted that society is hopelessly dismembered. The mutilation of the family body returns in a more precise way in Little voices (Carrillo \& Andrade 2010) and in The colors of the mountain (Arbeláez, 2010) to continue reiterating until the most recent Dos Mujeres y una Vaca (Bahamon, 2016). The family object is first mutilated by the murder of loved ones and then by the amputation of the beloved homeland. The expulsion of the homeland is sublimated in object of loss that is missed. That absence of the rapture makes the place of refuge always hostile and incomparable with the original as shown by the three films mentioned above.

The field that is associated as object of life and sustenance for the peasant is changed instead of danger and dispute that make it in no man's land. In earlier films such as El Ptro Chusmero (Sánchez, 1985) the peasant must go or run the risk of being killed but he does not because his family is buried there. Here the family is the land to which it returns and integrates after death. Here land and family are one. At the other extreme Retrato de un mar de mentiras (Restrepo, 2010) proposes the impossibility of recovering the lost but triggers more suffering. The illusion of returning to the territory comes into dispute because the country man can not live there to work and extract the fruits of his inheritance. No-man's land configures the displaced object. In that land, evil continues to lurk and not incarnate in a particular actor that generates violence, but in latent evil, as La Sirga (2012) and La Playa D.C. (2012). The instrument of violence is not represented in an actor or recognizable entity such as guerrillas or paramilitaries. Now it is terror has a spectral character, faceless, is almost a ghost that chases the victim and force her to be an individual in permanent transit. In that situation the family suffers the injuries inflicted on some of its members, but the mother comes to be in charge of keeping cohesion what is left. She is the mother of Jazmin in Pequeñas voces (Carrillo \& Andrade, 2010) who acts as mother and father after the murder of her husband, the teacher in Los colores de la montaña (Arbeláez, 2010) who continues with her classes despite the threats of the violent because it maintains the duty towards its students whom it sees like its children, and is the grandmother in Dos Mujeres y una Vaca (Bahamon, 2016) that accompanies to its granddaughter in the search of her husband. From the second decade of the twenty-first century it is observed that the phenomenon of displacement is diverse and even not entirely associated with violence but maintains the idea of mutilation as a consequence. Films that tell the individual who lost their land and roots because of nature in El Valle sin Sombras (Mendoza, 2015), the difficulty of exploiting the plot by the neighborhood with the modernity in Land and Shadow (Acevedo, 2015), the end of an occupation in Monte Adentro (Alonso, 2015) or the immigrant in Colombia in Paradar Húngaro (Suárez, Aleksander, 2015). In the extensive national filmography on violence, it can be observed that of the multiple representations of the displaced the mutilated family body is perhaps the most forceful expression of the phenomenon.

Even so, it is necessary to add that in spite of the forcefulness of these representations the national cinema on the violence has standardized to the displaced subject in the figure of the peasant. That is, all the displaced are peasants and these are one people. The diaspora is understood as the forced abandonment of a people of its territory. That people is united by a common culture that designates it as a community. Colombia is a 
pluricultural and diverse country with more than sixty languages that do not reach to personify all the cultures that live here. However, the national cinema has not presented to the cultures that have been victims of displacement. In fact, according to the United Nations High Commissioner for Refugees (UNHCR), the Colombian government's Victims Unit reports that during the last three decades of armed conflict the country has registered about 8.3 million victims, "close of 17 percent of the total population" (UNHCR, Feb. 2017, p. 2). Of this number, the same entity states "More than two thirds of the people affected were part of the indigenous population and the rest were Afro-Colombians and peasants" (UNHCR, Feb. 2017, p. 2). What is signified means that in Colombia one should not only speak of a diaspora but of diasporas because they are different cultures that pressured by the violence have been forced to leave their lands inside the Colombian territory. Unfortunately the filmmakers have forgotten cultural and ethnic diversity. If the filmography reports this, now or later, the map of representations and social imaginaries about violence and the way of representing the victim will be reconfigured. Particularly, cultures that try to survive on the periphery of the big city and are forced to accept other modus vivendi, another culture and even another sense of society, what chance do they have of preserving their principles, speeches and interpretations of the world? Is not this victim double as he not only uproots his territory but his culture? Given the optimism of the signing of peace agreements, national filmmakers have a duty to look at the ways in which the territories are being reconfigured, starting with the one left by the displaced person and the one that received it or was forced to take it. Thus, the analysis presented here not only gives an account of the representations and social imaginaries that the national cinema has expressed about violence and the displaced, but of what has still been left out.

\section{References}

ACNUR. (2017). ACNUR. UNHCR ACNUR. SITUACIÓN COLOMBIA Colombia, Ecuador y Venezuela Febrero 2017 (SITUATION COLOMBIA Colombia, Ecuador and Venezuela February 2017). Retrieved from http://www.acnur.org/fileadmin/scripts/doc.php?file=fileadmin/Documentos/BDL/2017/10938

Albaitero, M. J. E. (2001). Cornelius Castoriadis: sus conceptos (Cornelius Castoriadis: His concepts). Retrieved from $\mathrm{http}: / / 148.206 .107 .15 /$ biblioteca_digital/capitulos/21-524ith.pdf

Arango, J. A., Botero, B. J. A., Bustamante, E. D., Guevara, L. C., Solís, J., Murillo, A., Canniccioni, N., ... Art Mattan Productions. (2012). La playa D.C. (The beach D.C.).

Araya Umaña, S. (2002). Las representaciones sociales: Ejes teóricos para su discusión (The social representations: Theoretical axes for discussion). Retrieved from http://unpan1.un.org/intradoc/groups/public/documents/ICAP/UNPAN027076.pdf

Arbeláez, C. C., Montilla, C., Oriol, C., Jiménez, O., Ocampo, H. M., Sánchez, L. N., \& Aristizábal, G. A. (2011). Los colores de la montaña (The mountain colors). Bois-Colombe: Les Films du Paradoxe [édi., distrib.].

Augusto, A. C., Bustamante, E. D., Forero, J., Leal, H., Ruiz, H., Raigosa, E., ... Strand Releasing (Firm). (2015). La tierra y la sombra (Landandshade).

Baczko, B., Baczko, B., \& Baczko, B. (1991). Los imaginarios sociales: memorias y esperanzas colectivas/Les imaginaires sociaux (Social imaginaries: Collective memories and hopes). Retrieved from https://imaginariosyrepresentaciones.files.wordpress.com/2015/09/baczko-bronislaw-los-imaginarios-sociales.pdf

Banchs, M. A. (1986). Concepto de representaciones sociales. Análisis comparativo (Concept of social representations comparative analysis). Retrieved from http://rcps-cr.org/wp-content/uploads/2016/05/1986.pdf

Bárbara Films. (2016). Siembra (Sowing). Santiago Lozano y Ángela Osorio, Director. Distribuida por: CINEPLEX.

Becerra, S. (2016). Memoria visual del conflicto armado en Colombia: Recopilación histórica de filmografia sobre el conflicto armado en Colombia (Visual memory of the armed conflict in Colombia: Historical compilation of the filmography about the armed conflict in Colombia) (05/2016). Public Event, Cine Club Universidad Central. Bogotá.

Becerra, S. (2017). En torno a camilo Torres y el movimiento estudiantil (Around Camilo Torres and the student movement). In M. Mestman (Ed.), Las rupturas del 68 en el cine de América Latina (The ruptures of 68 in Latin American cinema) (pp. 217-248). Ediciones AKAL. 
Canal. G. (1959). Esta fue mi vereda (This was my town). 23 Min. Antares Films, con la cooperación de las Fuerzas Armadas, Ecopetrol y Banco Central Hipotecario.

Capetillo Hernández, J. (1991). El otro, lugar de deseo y de goce. Semiosis (The other, place of desire and enjoyment). Retrieved from http://cdigital.uv.mx/handle/123456789/6451

Carrillo, J. E. (2012). Pequeñas voces (Small voices). Madrid: Sony Pictures Home Entertainment.

Castaño, P., \& Trujillo, A. (1989). La ley del monte (Out of law). Robert Lamb, Paúl Clearey, Peter Jarvis, Productor Ejecutivo.

Castilla, C. E. (2001). El conflicto armado colombiano en los años noventa: cambios en las estrategias y efectos económicos (The Colombian armed conflict in the 1990s: Changes in the strategies and economic effects). Retrieved from https://colombiainternacional.uniandes.edu.co/view.php/374/index.php?id=374

Castoriadis, C. (1997). El imaginario social instituyente (The instituting social imaginary). Retrieved from http://www.ubiobio.cl/miweb/webfile/media/267/Castoriadis\%20Cornelius\%20-\%20El\%20Imaginario\%20Social\%20Institu yente.pdf

Castoriadis, C. (1998). El ascenso de la insignificancia (The ascent in insignificance). Universitat de València.

Cegarra, J. (2012). Fundamentos teórico epistemológicos de los imaginarios sociales (Epistemological theoretical foundations of social imaginaries). Retrieved from http://www.facso.uchile.cl/publicaciones/moebio/43/cegarra.html

Colombiana de televisión, RTI televisión, Cine Colombia. (1990) Amar y vivir. Carlos Duplat Director, Germán Escallón, guion. Exhibición theatrical Colombia.

Compañía de Fomento Cinematográfico., \& Pinzón, L. (1985). Pisingana. Bogotá: FOCINE.

Cristo, J., Andrade, H., Londoño, J., Barreras, R., Hurtado, H., \& Avellaneda, L. (2011). Colombian Congress. LEY 1448 DE 2011. Recuperada del sitio de la Alcaldía de Bogotá (LAW 1448 OF 2011: The site of Town hall of Bogotá). Retrieved from http://www.alcaldiabogota.gov.co/sisjur/normas/Norma1.jsp?i=43043

De la Maza, L. M. (2015). Sobre el espiritu en Hegel y Edith Stein (On the spirit in Hegel and Edith Stein). Retrieved from https://dx.doi.org/10.4067/S0049-34492015000200006

Doble sentido. (2016). Dos mujeres y una vaca (Two women and a cow). Efraín Bahamon, Director. Distributed by: CINEPLEX.

Dynamo \& Patagonik Films. (2013). Roa. Andrés Baiz, Director. Patricia Castañeda, Guion. Cine Color: Colombia \& Argentina.

Erreguerena Albaitero, M. (2001). Cornelius Castoriadis: sus conceptos (Cornelius Castoriadis: His concepts). Retrieved from https://publicaciones.xoc.uam.mx/Busqueda.php?Terminos=Cornelius+Castoriadis\%3A+sus + conceptos\&TipoMaterial=1\&I ndice $=1$

Fernández, A. M. (2016). La imaginación colectiva y anónima: introducción a algunas ideas de C. Castoriadis (The collective and anonymous imagination: Introduction to some ideas of C. Castoriadis). Retrieved from http://revista.diferencias.com.ar/index.php/diferencias/article/viewFile/58/25

Flórez, R. (2008). Heridas (Wounds). Roberto Flórez Prieto, Director. Carlos Alberto Franco Esguerra co-escritor. Proimagenes Colombia.

Gálvez, M. C., Gómez, J. O., Hernández, V., Londoño, G., Cardona, R. A., Chicago Latino Cinema., \& Facets Multimedia (Chicago, Ill.). (1990). Confesión a Laura (Confessionto Laura).

García, H. A. O. (2016). El vocabulario jurídico panhispánico. Contribuciones al español jurídicol (The pan-Hispanic legal vocabulary: Contributions to legal Spanish 1 ). http://www.academiacolombianadelalengua.co/wp-content/uploads/2016/11/BOLETIN-COMPLETO-271-272-NOV-1-6-1.p df\#page $=108$

Garcia, M. G., Malangon, S., Triana, J. A., Grupo Colombia (Film), \& Producciones Amaranta. (1996). Edipo alcalde (Oedipus mayor). México, D.F: Zafra Video.

Gaviria, C., Gómez, L., Baldion, P., Arango, A. M., Lizarazo, C., Ramos, R., ... Producciones Erwin Goggel. (2010). Retratos en un mar de mentiras (Portraits in a sea of lies). Colombia: Producciones Erwin Goggel.

Gaviria, V., Vásquez, E., Calle, G., Trujillo, A. M., Meneses, R., Restrepo, C. M., ... Video Factory (Firm). (1990). Rodrigo D: No futuro (Rodrigo D: Not future). Bogotá: Proimágenes en Movimiento.

Giraldo, D. (1966). Camilo Torres Restrepo. Universidad nacional de Colombia. Patrimonio Fílmico Colombiano.

Gubern, R. (1992). Historia del cine (History of cinema). Barcelona: Editorial Barber S.A.

Guerrero, F. (2016). Oscuro animal (Dark animal). Felipe Guerrero, Director. Distribuited by: MUTOKINO.

Hnos. Acevedo. (1932). El Perú nos invade (Peru invades us). Casa cinematográfica Colombia.

Hnos. Acevedo. (1946). Semana de la democracia en Bogotá (Week of democracy in Bogotá). Casa cinematográfica Colombia.

Hnos. Acevedo. (1948). El Bogotazo. Casa cinematográfica Colombia. 
Jambrina, P. P., \& Ruiz, M. A. (1926). Garras de oro (Golden claws). Cali Films (Colección cine silente colombiano).

Kusmanich, D. (1981). Canaguaro. Producciones Alberto Jiménez, Corporación Financiera Popular FONADE.

Landes, A., \& Kanopy (Firm). (2012). Porfirio. Francisco Aljure ... executive producer / producer. Nicolás Avruj ... co-producer. Macario, A. (2015). Monte adentro (Mount inside). Nicolás Macario Alonso.

Melo, G. J. C., Burgos, L., Hualpa, C., \& Lozano, L. (2014). Jardin de Amapolas (Poppy Garden). S.1.: Cineglobal Filmverleih.

Mendoza, R. (2015). El valle sin sombras (The valley without shadows). Diafragma fábrica de películas.

Molano, A. (2015). Fragmentos de la historia del conflicto armado en Colombia (1920-2010) (Fragments of the history of the armed conflict in Colombia (1920-2010)). Retrieved from http://www.corteidh.or.cr/tablas/33246.pdf

Mora, M. (2002). La teoría de las representaciones sociales de Serge Moscovici (The theory of social representations according to Serge Moscovici). Retrieved from http://www.raco.cat/index.php/Athenea/article/viewFile/34106/33945

Morin, E. (2001). La realidad semiimaginaria del hombre (The semi-imaginary reality of man). In El cine o el hombre imaginario (The cinema or the imaginary man) (No. 791.4 M858c). Barcelona, ES: Paidós.

Moscovici, S. (1979). La representación social: un concepto perdido (Social representation: A lost concept). Retrieved from http://cholonautas.edu.pe/modulo/upload/tallmosc.pdf

Moscovici, S., \& Hewstone, M. (1963). De la ciencia al sentido común (From science to common sense). Retrieved from https://es.scribd.com/document/95070846/De-la-ciencia-al-sentido-comun-Moscovici

Muel, B., \& Sergent, J. P. (1965). Río Chiquito (Chiquito River). Francia.

Muel, B., \& Sergent, J. P. (1966). Camilo Torres. Francia.

Naranjo, G., \& Hurtado, D. (2004). Ciudades y desplazamiento forzado en Colombia: El "reasentamiento de hecho" y el derecho al restablecimiento en contextos conflictivos de urbanización (Cities and forced displacement in Colombia: The "de facto resettlement" and the right to resettlement in conflictive urbanization contexts). Retrieved from https://www.researchgate.net/profile/Gloria_Naranjo_Giraldo/publication/266471591_CIUDADES_Y_DESPLAZAMIENT O_FORZADO_EN_COLOMBIA_El_reasentamiento_de_hecho_y_el_derecho_al_restablecimiento_en_contextos_conflictiv os_de_urbanizacion/links/55672cbf08aefcb861d3835b.pdf

Navarrete Cardona, S. (2014). La historia de la primera restitución de tierras en una zona de reserva forestal (The history of the first restitution of lands in a forest reserve area). Retrieved from http://www.elespectador.com/noticias/judicial/historia-de-primera-restitucion-de-tierras-una-zona-de-articulo-530832

Nieto, J., Gómez, J. A. M., \& Moya, R. A. T. (2005). Largometrajes colombianos en cine y video: 1915-2004 (Colombian feature films in film and video: From 1915 to 2004). Retrieved from http://patrimoniofilmico.org.co/descarga/

Norden, F. (1985). Cóndores no entierran todos los días (The condors do not bury every day). Colombia: Fondo Mixto de Promoción Cinematográfica - Proimagen.

Oubiña, D. (2017). El profano llamado del mundo (The profane called of the world). In M. Mestman (Ed.), Las rupturas del 68 en el cine de América Latina (The ruptures of 68 in Latin American cinema) (pp. 65-124). Ediciones AKAL.

Palacio, A., \& Quintero, F. (2002). Secuestro aéreo, puntillazo final (Air hijacking, final puncture). Retrieved from http://www.eltiempo.com/archivo/documento/MAM-1308661

Ramírez, J. (2015). Cartilla de historia de cine colombiano (History booklet of Colombian cinema). Retrieved from http://www.mincultura.gov.co/areas/cinematografia/publicaciones/Documents/Cartilla\%20Historia\%20del\%20Cine $\% 20$ Colo mbiano\%202015.pdf

Restrepo, L. A., Lizarazo, C., Toro, J. A., Méndez, H., Video Factory (Film), \& Corporación Fondo Mixto de Promoción Cinematográfica-Proimagenes en Movimiento (Colombia). (2003). La primera noche (The first night). Bogotá, Colombia: Proimagenes en Movimiento.

Restrepo, L. D. Q. (2009). Los pájaros del valle del cauca (The vultures of the Valle del Cauca). Retrieved from file://Users/luisfernando/Downloads/851-2919-1-PB.pdf

Riffo Pavón, I. (2016). Una reflexión para la comprensión de los imaginarios sociales (A reflection for the understanding of social imaginaries). Retrieved from http://www.scielo.org.pe/scielo.php?pid=S2219-71682016000100006\&script=sci_arttext

Robertazzi, M. (2007). Representaciones sociales e imaginario social (Social representations and social imaginary). Retrieved from http://23118.psi.uba.ar/academica/carrerasdegrado/psicologia/informacion_adicional/obligatorias/036_psicologia_social2/rep resentaciones.pdf

Rodríguez, M., Silva, J., Colombia., \& Fundacion Cine Documental. (1972). Chircales (The brickmakers). Colombia: Fundacion Cine Documental Investigación Social [distributor]. 
Said, A. (2015). Parador Húngaro (Hungarian hostel). Aseneth Suárez Ruiz, Patrick Alexander. ROYAL FILMS.

Salcedo, H. (1981). Crónicas del cine colombiano 1897-1950 (Chronicles of the Colombian cinema from 1897 to 1950). Bogotá, Colombia, Carlos Valencia Editores.

Sánchez, L. A. (1985). El potro Chusmero (The colt Chusmero-Chusmero is equivalent to plebs). Compañía de fomento cinematográfico, Focine.

Trujillo, S. (2015). Cine y politica (Cinema and politics). Retrieved from http://www.cinematecadistrital.gov.co/content/cine-y-pol\%C3\%ADtica-cuaderno-no23

Umaña Gallego, J. (2017). El cine colombiano ha crecido, pero le falta público (Colombian cinema has grown, but it lacks audience). Retrieved

from http://www.elcolombiano.com/cultura/cine/el-cine-colombiano-ha-crecido-pero-le-falta-publico-EK6059053

Vega, W., Ruiz, N. O., Arias, J. S., Robles, J. C., Achicanoy, F., Guacas, D., ... Film Movement (Firm). (2012). La sirga. New York: Film Movement. 